O. I. Aauiü,

д. е. н., професор, завідувач кафедри фінансів, банківськоӥ та страхової справи

Міжрегіональної академії управління персоналом

ORCID ID: 0000-0002-7436-3264

I. I. Туболещь,

к. е. н., дочент, дочент каредри державних, місиевих та корпоративних фінансів,

Університет митної справи та фінансів

ORCID ID: 0000-0002-4930-2427

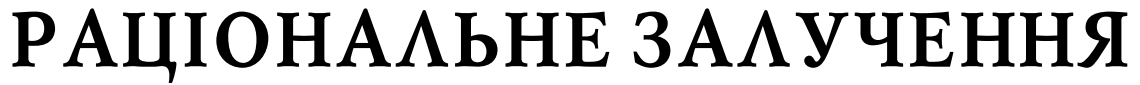 ТА ВИКОРИСТАННЯ ІНВЕСТИЦІЙ АИЯ ПІАПРИЕМСТВ АОРОЖНЬОГО ГОСПОААРСТВА
}

\author{
O. Datsii, \\ Doctor of Economics, Professor, Head of the Department of Finance, \\ Banking and Insurance of the Interregional Academy of Personnel Management \\ I. Tubolets, \\ Candidate of Economic Sciences, Associate Professor, Department of State, \\ Local and Corporate Finance, University of Customs and Finance
}

\section{RATIONAL INVESTIGATION AND USE OF INVESTMENT FOR ENTERPRISES OF ROAD ECONOMY}

Зазначено важливість дослідження та удосконалення термінологічного апарату таких дефініцій, як "інвестиційна діяльність", "інвестиційний процес". При цьому розглянуто значення теоретичних засад, що характеризують економічну сутність інвестицій, для визначення практичних підходів до вирішення проблем, які стосуються активізації інвестиційної діяльності підприємств і організацій дорожнього господарства.

Охарактеризовано необхідність посилення процесу використання зовнішніх і внутрішніх інвестиційних ресурсів, що надасть можливість реалізувати стратегічно важливі проекти державних та приватних підприємств і організацій, спрямовані на будівництво та оновлення автомобільних шляхів, забезпечення надійності функціонування інженерних мереж.

Наведено найбільш вагомі напрями реформування транспортної галузі України та системи управління автомобільними шляхами, застосування яких забезпечить значні переваги національної транспортної системи України та дозволить підготувати реальні шляхи ї̈ інтеграції до європейської та світової транспортних систем.

Вказано, що підтримка Європейського Союзу, іноземних банків, а також юридичних осібє фінансовим важелем здійснення глибоких перетворень транспортної галузі України та забезпечення результативної діяльності підприємств дорожнього господарства. До того ж важливим механізмом залучення інвестиційних ресурсів є застосування договору про концесію, що здійснюється у рамках державно-приватного партнерства. 
The important factors influencing the functioning of a market economy is indicated. The factors include the following: the introduction of active, practical steps to strengthen the investment activity of enterprises and organizations, maintaining the ability of the economic system to meet the needs of the population.

The importance of research and improvement of the terminological apparatus of such definitions as "investment activity", "investment process" are indicated. The significance of the theoretical foundations characterizing the economic nature of investments has been considered to determine practical approaches to solving problems related to the intensification of investment activities of enterprises and organizations of the road sector.

The concept of investment is generalized. Investments are defined as long-term investments in any kind of economic activity and profit as a consequence of these investments. Consequently, investments are defined as the investment of capital in all its forms into various objects of economic activity for the purpose of profit.

The necessity of strengthening the process of using external and internal investment resources are characterized.

The most important directions of reforming of the transport industry of Ukraine and automobile road management systems are presented. Application of such a complex of measures will provide significant advantages of the national transport system of Ukraine and will allow to prepare real ways of its integration into the European and world transport systems.

Support of the European Union, foreign banks, as well as legal entities is a financial lever for implementing profound transformations in the transport industry of Ukraine and ensuring the productive activity of enterprises of the road economy is ascertained. An important mechanism for attracting investment resources is the application of the concession agreement, carried out within the framework of public-private partnership is indicated.

The factors that hinder the practical use of positive results from the introduction of directions of reformation of the transport industry of Ukraine and automobile road management systems are presented.

It was noted that Investment activity is a set of practical actions of citizens, legal entities and the state in relation to investment realization. The objects of investment activity are described. It is ascertained that the following types of tangible property belong to objects of investment activity: fixed and working capital, securities, target cash deposits, scientific and technical products, intellectual values.

Ключові слова: держаВно-приВатне партнерстВо, договір концесії, інВестиції, інВестиційна діяльність, інВестиційний процес, підприємстВа дорожнього господарства.

Key words: public-private partnership, concession agreement, investment, investment activity, investment process, enterprises of road economy.

\section{ВСТУП}

Автомобільні шляхи України відіграють важливу роль у функціонуванні наземної транспортної магістралі, оскільки по Україні проходять чотири із десяти Міжнародних транспортних коридорів. Інфраструктура транспортної магістралі повинна забезпечувати безпеку перевезення пасажирів та вантажів, тому обслуговування автомобільних доріг, допоміжних споруд, під'їзних шляхів підприємствами дорожнього господар- ства $€$ необхідним завданням. До того ж якість автомобільних доріг має суттєвий вплив на розвиток національної економіки країни.

\section{ПОСТАНОВКА ЗАВААННЯ}

Якість мереж автомобільних шляхів державного та місцевого значення $\epsilon$ важливою складовою, що визначає ефективність фрункціонування суб'єктів господарювання та здатність національної економіки як єдиної 
системи, що об'єднує види економічної діяльності, до суперництва та співробітництва 3 іншими країнами. Удосконалення дорожнього покриття $€$ невід'ємним чинником, що забезпечує безпечне та якісне перевезення пасажирів, а також готової продукції і сировини. Актуальність зазначеного фактору посилюється активізацією процесу створення стійких взаємозв'язків між державами.

Підтримання належного рівня якості мереж автомобільного сполучення України відбувається за рахунок зусиль підприємств дорожнього господарства. Проте експерти визначають, що автомобільні дороги в Україні є одними з найгірших у світі, тому й досі гострим питанням залишається залучення додаткових джерел фрінансування діяльності підприємств дорожнього господарства. Окреслення зазначених проблем розкриває необхідність посилення інвестиційної діяльності.

\section{РЕЗУ АЬТАТИ}

Проблеми інвестиційної діяльності досліджувало багато українських та зарубіжних науковців. Серед фундаментальних досліджень теоретичних і практичних аспектів інвестиційної діяльності виділимо праці таких вчених: І.О. Бланк, Л.М. Борщ, В.О. Буряк, О.В. Гаврилюк, М.С. Герасимчук, А.Ф. Гойко, Б.В. Губський, Я.Д. Крупка, І. Малий, Л.І. Нейкова, А.А. Пересада, С.К. Реверчук, Д.М. Черваньов.

Аналіз залучення та використання інвестицій проводився у працях О.М. Алимова, І.А. Бланка, Л.Дж. Гітмана, М.П. Денисенка, О.А. Джусова, С.І. Дорогунцова, М.І. Іванова, Дж.М. Кейнса, М. Портера, У. Шарпа та інших.

Проте не всі аспекти зазначеної проблеми достатньо з'ясовані та обгрунтовані. Дослідження та удосконалення потребує термінологічний апарат таких дефініцій, як "інвестиційна діяльність", "інвестиційний процес". Зростає необхідність глибшого вивчення й аналізу чинників, що знижують ефективність залучення інвестиційних ресурсів у транспортну галузь України, а також подальшого опрацювання вимагає визначення напрямів реформування цієї галузі.

Серед головних завдань, вирішення яких має значний позитивний вплив на процес вдосконалення та поширення ринкових відносин в Україні, створення системи, що забезпечує співробітництво та взаємозв'язок між сегментними ринками в середині країни, $€$ забезпечення належних умов та реальної потенційної дійсності, що дозволить розвивати транспортну галузь України, а також забезпечити ефективне функціонування підприємств дорожнього господарства, враховуючи їх специфріку, на засадах ефективного використання економічних ресурсів.

Якісно нові зміни, що відбуватимуться у транспортній галузі України обумовлюють транзитні можливості країни, а їх здійснення позитивно позначається на рентабельності багатьох видів економічної діяльності. 3 метою прискорення глибоких перетворень у транспортній галузі зростає необхідність посилення процесу використання зовнішніх і внутрішніх інвестиційних ресурсів, що дозволить втілити у життя стратегічно важ- ливі проекти державних та приватних підприємств і організацій, спрямованих на будівництво та оновлення автомобільних шляхів, забезпечення надійності фрункціонування інженерних мереж, а також встановлення високих стандартів транспортного забезпечення логістики.

У сучасних умовах прискорення рівня розвитку новітніх технологій зростає необхідність залучення інвестиційних ресурсів, які виступають вагомою основою для здійснення значних змін, що стосуються структурних перетворень національної економіки, покращення показників суб'єктів господарювання. Отже, інвестиції $€$ переважно важливим фактором економічного зростання. До того ж, кризовий стан світової економіки підкреслює актуальність проблеми залучення інвестицій.

Географрічне положення України виокремлюється вигідним розташуванням, а також сукупністю характеристик, серед яких торговельні шляхи, що здійснюють вплив на зміни у соціальному та політичному устрої. Такі особливості надають гарні перспективи для розвитку України як транзитної держави між східними й південноазіатськими ринками, а також приваблює потенційних інвесторів.

Необхідність посилення інвестиційного процесу в Україні, а також збільшенню діапазону інвестиційної діяльності держави і підприємств обумовлено змінами, що викликані встановленням і розвитком ринкової економіки.

На думку зарубіжних та вітчизняних дослідників, фрункціонування ринкової економіки грунтується на основі покращення якісних та кількісних характеристик самостійних суб'єктів господарювання, а також врахуванні фракторів економічного зростання. Вагомими чинниками, що впливають на функціонування ринкової економіки є впровадження активних, практичних дій щодо посилення інвестиційної діяльності підприємств та організацій, підтримання здатності економічної системи задовольняти потреби населення країни, нарощування потенціалу економіки країни, що дозволить конкурувати з іншими країнами світу $[4 ; 5]$.

Практичні аспекти рішення цих проблем повинні грунтуватися на чітких теоретичних позиціях, що стосуються тлумачення економічної сутності інвестицій та їх найважливіших складових, а також розуміння сутності інвестиційної діяльності та інвестиційного процесу.

Дослідження засад інвестиційної діяльності активно проводять вітчизняні та зарубіжні вчені, тому термін "інвестиції" є багатоаспектним і має декілька фрормулювань. Інвестиції - це:

- купівля акцій та облігацій [5];

- реальні активи, які необхідні для виробництва товару [1];

- механізм, який забезпечує фінансове зростання та розвиток економіки регіону [5].

У Законі України "Про інвестиційну діяльність" [3] визначено, що інвестиції - це всі види майнових та інтелектуальних цінностей, що вкладаються в об'єкти підприємницької діяльності, в результаті якої отримується прибуток або досягається соціальний ефект, а 
інвестиційна діяльність - це сукупність практичних дій громадян, юридичних осіб і держави щодо їх реалізації. Для формування регіональної політики останнє визначення $€$ пріоритетним, тому що воно набуває нормативного характеру.

Теоретичні проблеми виникають при ототожненні понять "інвестиційна діяльність" та "інвестиційний процес". Так, Л.Дж. Гітман "інвестиційний процес" трактує його як механізм, який об'єднує тих, хто пропонує тимчасово вільні кошти, з тими, хто їх потребує [1].

На думку вчених, інвестиційний процес - більш узагальнене та об'ємне поняття, ніж інвестиційна діяльність. Перше охоплює більшу кількість відносин та учасників, рівнів управління, а друге - концентрується на рівні підприємств. Крім того, інвестиційний процес складається зі стадій: фінансування інвестицій; освоєння інвестицій; мотивацією інвестиційної діяльності; обгрунтування доцільності інвестицій [5].

Розвиток інвестиційного процесу повинен стимулювати: становлення крупних бюджетних і позабюджетних фондів інвестиційної і інноваційної спрямованості. Важливими складовими також можуть бути важелі, які підсилюють інвестиційну діяльність, що сприяє створенню сприятливіших умов для іноземних інвесторів. Зарубіжні та вітчизняні дослідники характеризують інвестиційний процес як такий, що об'єднує суб'єкти, які здійснюють пропозицію коштів тим суб'єктам, які відчувають в них потребу. У. Шарп інвестиційний процес ототожнює 3 рухом цінних паперів, А. Пересада - з інвестиційним циклом, розкриваючи його в стадіях: мотивація, прогнозування інвестиційної діяльності, державне регулювання, страхування, підготовка до виробництва продукції тощо [4].

Інвестиційна діяльність - це сукупність практичних дій громадян, юридичних осіб і держави щодо реалізації інвестицій [5]. До об'єктів інвестиційної діяльності відносять такі види матеріального майна:

- основні і оборотні кошти (стосовно до всіх галузей економіки);

- цінні папери (акції, облігації, векселі тощо);

- цільові грошові вклади;

- продукція науково-технічного характеру;

- інтелектуальні цінності;

- інші права, пов'язані з майном.

Узагальнено під інвестиціями розуміють довгострокове вкладення коштів у будь-які види економічної діяльності та отримання прибутку як наслідок цих вкладень. Отже, інвестиції визначають, як вкладення капіталу у всіх його формах в різні об'єкти (інструменти) господарської діяльності з метою отримання прибутку, а також для досягнення іншого економічного або позаекономічного ефекту, здійснення якого базується на ринкових принципах і пов'язане з факторами часу, ризику і ліквідності [1].

Інвестиції розглядають як вкладення капіталу в рухомі і нерухомі об'єкти господарської діяльності, як джерело розширення і процвітання підприємництва, як окремий економічний об'єкт ринкових відносин, а також як можливу причину або носій ризику, пов'язаного з їх вкладенням.
В економічній літературі поняття інвестиції розглядається багатогранно і різнобічно. В залежності від напрямів і цілей використання такої економічної категорії, інвестиції можуть бути об'єктом економічного управління і найголовнішою формою або способом залучення капіталу в господарський процес. У залежності від джерел фрінансування інвестиції можуть бути внутрішні та зовнішні.

Варто зазначити, що необхідність посилення процесу використання зовнішніх і внутрішніх інвестицій зумовлено актуальністю прискорення глибоких перетворень у транспортній галузі України, а також зростання значимості діяльності підприємств з обслуговування автомобільних шляхів та інженерних мереж. Але складні проблеми країни, які характеризуються несприятливою політичною, економічною та соціальною нестабільністю, низьким рівнем розвиненості відносин, які виникають у процесі обслуговування певними організаціями, установами та підприємствами різних видів ринку, існування тіньової економіки в Україні негативно впливають на залучення іноземних інвестицій. Проте дослідники відзначають, що одночасно з цим в Україні існують фактори, які зацікавлюють іноземних інвесторів: місткий ринок, низька ціна робочої сили, вигідне географрічне положення, сприятливі кліматичні умови тощо.

На думку дослідників, вагомим фрінансовим важелем реалізації комплексу заходів, що забезпечать глибокі перетворення транспортної галузі України та результативну діяльність підприємств дорожнього господарства є підтримка Європейського Союзу, іноземних банків, а також юридичних осіб, що забезпечують організацію та технічне обслуговування руху фондів грошових коштів. Така допомога здійснюється у фрормі надання фрінансової підтримки державному бюджету, виділення позик на реалізацію проектів підприємств та організацій, спрямованих на модернізацію транспортної галузі України. До того ж одним із засобів залучення зовнішніх і внутрішніх інвестицій може бути державно-приватне партнерство, у рамках якого здійснюється укладання договору про концесію [2].

Формування економічних зв'язків між резидентами різних держав, які характеризують відносини, що складаються між світовими виробниками товарів, а також поширення туристичних послуг серед населення світу обумовлюють застосування комплексу заходів, що забезпечить значні переваги національної транспортної системи України та дозволить підготувати реальні шляхи її інтеграції до європейської та світової транспортних систем. Застосування таких заходів означає реформування транспортної галузі України, а разом $з$ тим і реформування системи управління автомобільними шляхами, будівництво і обслуговування яких виконують підприємства дорожнього господарства.

До найбільш вагомих напрямів рефрормування транспортної галузі України та системи управління автомобільними шляхами, уряд відносить наступні:

- заснування цільового фонду, що призначений для нагромадження державою фрінансових ресурсів, не- 
обхідних для створення, перебудови та удосконалення автомобільних шляхів державного та місцевого значення;

- встановлення системи, що стягуватиме плату 3 великовантажних транспортних засобів за проїзд автомобільними шляхами для відшкодування негативних наслідків, що завдаються автомобільним дорогам;

- покращення системи контролю за технічними параметрами дорог, що призначені для руху транспортних засобів, а також забезпечення оцінки якості, проведених дорожніх робіт, що дозволить забезпечити безпеку перевезення пасажирів та вантажів.

- впровадження у сфрері будівництва автомобільних дорог типових форм контрактів Міжнародної федерації інженерів-консультантів (FIDIC) [2].

До фракторів, які перешкоджають практичному використанню позитивних результатів, що можливо отримати від запровадження напрямів реформування транспортної галузі України та системи управління автомобільними шляхами, відносять такі:

- негативний вплив на діловий клімат у державі, що здійснюється через нестабільність економічної ситуації, а також бюрократичні бар'єри на шляху отримання необхідних дозволів зумовлюють незацікавленість юридичних осіб у прийманні участі в проектах та розміщенні власних коштів;

- відсутність необхідного досвіду щодо укладання та виконання договорів концесії в Україні; способів та прийомів оцінювання ризиків, а також застосування реальних механізмів їх розподілу; досвіду забезпечення з боку держави умов договорів концесії протягом визначеного терміну; гарантій покриття ризику щодо повернення коштів, використаних на підготовку обгрунтування економічної доцільності реалізації проекту, у разі його відхилення конкурсною комісією; встановлення розміру оплати за проїзд автомобільними дорогами, що передано у концесію;

- тривалий період концесійного управління (до 50 років, якщо інше не передбачено умовами договору), внаслідок чого складно обгрунтувати економічний ефект від впровадження довгострокового проекту [2].

Отже, враховуючи отримання позитивних результатів від впровадження комплексу заходів, які можуть забезпечити структурні зміни у транспортній системі України, а також перешкоди на шляху застосування реформ, відзначимо, що необхідність посилення інвестиційної діяльності зростає. Це пояснюється важливістю розвитку України як транзитної держави, що в свою чергу потребує підтримання належного рівня якості мереж автомобільного сполучення, чим займаються підприємства дорожнього господарства.

\section{ВИСНОВКИ}

Значення інвестицій для покращення показників діяльності підприємств дорожнього господарства, а також реалізації системних перетворень транспортної галузі зростає. Враховуючи це, посилення процесу використання інвестицій $є$ важливим завданням. Інвестиції розглядають як об'єкт економічного управління і найголовнішу форму або спосіб залучення капіталу в гос- подарський процес, інвестиційну діяльність як дії юридичних та фрізичних осіб з раціонального залучення та використання інвестицій реалізації інвестицій, а інвестиційний процес як механізм, що складається з наступних стадій: фрінансування інвестицій; освоєння інвестицій; мотивацією інвестиційної діяльності; обгрунтування доцільності інвестицій.

Застосування практичних та активних дій щодо активізації інвестиційної діяльності підприємств та організацій дорожнього господарства, що проявляється у залученні внутрішніх та зовнішніх інвестицій, $є$ вкрай необхідним для реалізації проектів, спрямованих на будівництво та оновлення автомобільних шляхів, забезпечення надійності функціонування інженерних мереж, а також встановлення високих стандартів транспортного забезпечення логістики. Структурні зміни у транспортній галузі України, а також зростання значимості діяльності підприємств дорожнього господарства зумовлює потребу у застосуванні договору про концесію, що здійснюється у рамках державноприватного партнерства, для отримання інвестиційних ресурсів.

\section{Література:}

1. Гитман Л.Дж. Основы инвестирования / Л.Дж. Гитман, М.Д. Джонк; [пер. с англ.]. - М.: Дело, 1997. 393 c.

2. Інвестиційні механізми структурних трансорормацій у транспортній галузі. Аналітична записка [Електронний ресурс] / О.В. Собкевич, О.Ю. Ємельянова // Національний інститут стратегічних досліджень. URL: http://www.niss.gov.ua/articles/995/

3. Про інвестиційну діяльність: Закон України від 18.09.1991 р. № 1560-XII. Із змінами та доповненнями, внесеними Законом України від 08.06.2017 р. № 2095VIII. URL: https://zakon.rada.gov.ua/laws/show/156012

4. Пересада А.А. Фінансові інвестиції: [підручник] / А.А. Пересада, Ю.М. Коваленко. - К.: КНЕУ, 2006. $728 \mathrm{c}$.

5. Шарп У. Инвестиции / У. Шарп, Г. Александер, Д. Бейли; [пер. с англ.]. — М.: ИНФРА-М., 1997. - 1024 с.

References:

1. Gitman, L.Dzh. and Dzhonk, M.D. (1997), Osnovyi investirovaniya [Fundamentals of investing], Delo, Moscow, Russia.

2. The official site of National Institute for Strategic Studies (2018) "Investment mechanisms for structural transformations in the transport industry", available at: http:/ / www.niss.gov.ua/articles/995/ (Accessed 4 April 2019).

3. The Verkhovna Rada of Ukraine (1991), The Law of Ukraine "About investment activity", available at: https:/ /zakon.rada.gov.ua/laws/show/1560-12 (Accessed 4 April 2019).

4. Peresada, A.A. and Kovalenko, Yu.M. (2006), FInansovi Investitsiyi [Financial investments], KNEU, Kyiv, Ukraine.

5. Sharp, U. Aleksander, H. and Bejly, D. (1997), Ynvestytsyy [Investments], YNFRA-M, Moscow, Russia. Cтаття надійшла до редакцї 08.04.2019 p. 